\title{
Akuntabilitas Pengelolaan Dana Desa di Kecamatan Kotamobagu Selatan Kota Kotamobagu
}

\author{
ASTRI JUAINITA MAKALALAG ${ }^{1}$, GRACE B NANGOI ${ }^{2}$, HERMAN KARAMOY ${ }^{3}$ \\ ${ }^{1,2,3}$ Program Studi Magister Akuntansi, Fakultas Ekonomi dan Bisnis Universitas Sam Ratulangi \\ email : makalalagastri@yahoo.com ${ }^{1}$, gracebn@yahoo.com², hkaramoy@yahoo.com ${ }^{3}$
}

\begin{abstract}
Village fund management requires the existence of good governance in which one of its pillars is accountability. The allocation of substantial funds is expected to give a significant impact on the welfare of rural communities and also can be reported and accounted for. Management of village fund should be done based on the principle of governance which are transparent, accountable and participatory. This research was conducted in six villages in the South Kotamobagu Districts of Kotamobagu city. 21 respondents were interviewed. They are the fund manager of the village and the village fund facilitator team. This study is a qualitative exploratory research. Data were analyzed by content analysis and technical analysis was the reduction, data presentation and conclusion. The results of this study indicate that the accountability of the village fund management in South Kotamobagu District in Kotamobagu city have been carried out and fulfilled in terms of transparency, accountability and participatory. Altough there were several omissions that still be conducted the by village officers and technical executors. In overall, the reporting and accountability have been implemented in accordance with the mechanism of provisions. Competency of management resources are still a major problem requiring the assistance of local government. To improve the accountability in the management of village funds; a sustainable coaching, training, supervision and evaluation to village authorities are needed.
\end{abstract}

Keywords: village fund management, accountability, transparency, participatory.

Abstrak. Dalam pengelolaan dana desa dituntut adanya suatu aspek tata pemerintahan yang baik (good governance) dimana salah satu pilarnya adalah akuntabilitas. Alokasi dana yang cukup besar diharapkan dapat memberikan dampak yang signifikan terhadap kesejahteraan masyarakat desa, dan benar-benar dapat dilaporkan serta dipertanggungjawabkan. Pengelolaan keuangan desa dilakukan berdasarkan prinsip tata kelola yaitu transparan, akuntabel dan partisipatif. Penelitian ini dilaksanakan di 6 (enam) desa dalam wilayah Kecamatan Kotamobagu Selatan Kota kotamobagu. Dengan jumlah informan 21 (dua puluh satu) orang yaitu pengelola dana desa dan tim fasilitasi dana desa. Penelitian ini menggunakan metode kualitatif eksploratif. Metode yang digunakan adalah analisis isi dan teknis analisis yang digunakan adalah reduksi, penyajian data dan penarikan kesimpulan. Hasil penelitian ini menunjukkan bahwa akuntabilitas pengelolan dana desa di Kecamatan Kotamobagu Selatan Kota Kotamobagu telah dilaksanakan berdasarkan prinsip transparan, akuntabel dan partisipatif. Dalam pelaporan dan pertanggungjawaban sudah dilaksanakan sesuai dengan mekanisme berdasarkan ketentuan walaupun masih terdapat kelalaian dari aparat desa dan pengelola teknis kegiatan. Kompetensi sumber daya pengelola masih merupakan kendala utama, sehingga masih perlu pendampingan pemerintah daerah. Untuk meningkatkan akuntabilitas dalam pengelolaan dana desa di Kecamatan Kotamobagu Selatan Kota Kotamobagu dibutuhkan pembinaan, pelatihan, pengawasan dan evaluasi secara berkelanjutan kepada aparat desa.

Kata Kunci : pengelolaan dana desa, akuntabilitas, transparansi, partisipatif.

\section{Pendahuluan}

Dalam sistem pemerintahan negara mempunyai peran strategis sebagai elemen kesatuan Republik Indonesia, desa dari pemerintah daerah khususnya 
Kabupaten/Kota dalam menyelenggarakan proses pembangunan. Semua itu dilakukan sebagai langkah nyata pemerintah pusat guna mendukung pelaksanaan otonomi daerah. Pemerintah desa merupakan strata pemerintahan paling bawah yang berhubungan langsung dengan masyarakat. Sehingga tingkat kepercayaan masyarakat atas pengelolaan pemerintah desa merupakan hal yang sangat penting dan dibutuhkan.

Berkaitan dengan peran tersebut, diatur dalam UU (undang-Undang) No.6 Tahun 2014 tentang Desa (selanjutnya disebut Undang-Undang Desa) yang menjelaskan bahwa desa merupakan masyarakat hukum yang memiliki batas wilayah yang berwenang untuk mengatur dan mengurus urusan pemerintahan, kepentingan masyarakat setempat berdasarkan prakarsa masyarakat, hak asal-usul dan/atau hak tradisional yang diakui dan dihormati dalam sistem pemerintahan negara kesatuan Republik Indonesia. Dengan adanya kewenangan yang diberikan ke pemerintahan desa, maka diharapkan desa dapat berkembang menjadi suatu wilayah yang maju, mandiri dan demokratis.

Untuk mewujudkan desa yang maju, mandiri dan demokratis, membutuhkan anggaran dalam pembangunan dan pemberdayaan masyarakat di suatu desa. Anggaran tersebut diatur dalam PP (Peraturan Pemerintah) No. 60 Tahun 2014 tentang Dana Desa yang menyebutkan bahwa dana desa adalah dana yang bersumber dari APBN (Anggaran Pendapatan dan Belanja Negara) yang diperuntukkan bagi desa yang ditransfer melalui APBD (Anggaran Pendapatan dan Belanja Daerah) Kabupaten/Kota dan digunakan untuk membiayai penyelenggaraan pemerintahan, pelaksanaan pembangunan, pembinaan kemasyarakatan dan pemberdayaan masyarakat. Berkaitan dengan pengelolaan dana desa, dijelaskan dalam Peraturan Menteri Dalam Negeri No. 113 Tahun 2014 tentang Pengelolaan Keuangan Desa. Proses pengelolaan dana desa dimaksud dimulai dari perencanaan, pelaksanaan, penatausahaan, pelaporan dan pertanggungjawaban. Semua proses pengelolaan dana desa harus didasari asas transparansi, akuntabel dan partisipatif. Dalam pengelolaan dana desa, dituntut adanya suatu aspek tata pemerintahan yang baik (good governance) dimana salah satu pilarnya adalah akuntabilitas.

Menurut Mardiasmo (2002) akuntabilitas adalah kewajiban pihak pemegang amanah untuk memberikan pertanggungjawaban, menyajikan dan mengungkapkan segala aktivitasnya dan kegiatan yang menjadi tanggungjawabnya kepada pihak pemberi amanah (principal) yang memiliki hak dan kewenangan untuk meminta pertanggungjawaban tersebut. Pemerintah Kota Kotamobagu merupakan salah satu daerah otonom yang ada di Provinsi Sulawesi Utara yang telah melaksanakan prinsip-prinsip otonomi daerah dengan berusaha mengoptimalkan potensi desa dengan mengalokasikan dana desa dalam APBD yang bersumber dari APBN.

Dari laporan penyaluran dan realisasi penggunaan dana desa tahap I tahun 2016 di 12 (dua belas) desa yang berada di 3 (tiga) Kecamatan, rata-rata realisasi penggunaan dana desa telah mencapai lebih dari $50 \%$. Namun masih ada beberapa desa yang realisasi penggunaan dana desa tahap I masih berada dibawah $50 \%$. Hal ini menunjukkan bahwa sejumlah desa yang ada di Kota Kotamobagu belum dapat merealisasikan penggunaan dana desa sesuai dengan ketentuan.

Demikian juga dalam penyampaian laporan realisasi pelaksanaan APBDes semester pertama dimana laporan laporan realisasi atau penggunaan dana desa yang merupakan bagian yang tak terpisahkan dari laporan realisasi APBDes semester pertama menunjukkan pemerintah desa terlambat dalam melaksanakan penyampaian kepada Walikota Kotamobagu.

Berdasarkan latar belakang yang diuraikan, maka rumusan masalah dalam penelitian ini adalah bagaimana "Bagaimana Akuntabilitas Pengelolaan Dana Desa dalam Pelaporan dan Pertanggungjawaban di Kecamatan Kotamobagu Selatan Kota Kotamobagu? 
Tujuan dalam penelitian ini adalah untuk menganalisis Akuntabilitas Pengelolaan Dana Desa dalam Pelaporan dan Pertanggungjawaban di Kecamatan Kotamobagu Selatan Kota Kotamobagu.

\section{Metode Penelitian}

Penelitian ini menggunakan metode kualitatif dengan pendekatan eksploratori (exploratory approach). Creswell (2012:206) dalam Sugiono (2015) menjelaskan bahwa dalam penelitian kualitatif, tujuannya adalah tidak untuk menggeneralisasi ke populasi, tetapi untuk mengembangkan eksplorasi mendalam terhadap inti fenomena.

Teknik pengumpulan data yang digunakan dalam penelitian ini adalah melalui wawancara, Observasi, dan Dokumentasi. Penelitian ini difokuskan di 6 (enam) desa yang ada di Kecamatan Kotamobagu Selatan Kota Kotamobagu. Metode analisis yang digunakan adalah content analysis (analisis isi). Metode ini merupakan bagian dari metode analisis teks dan bahasa (Satori dan Komariah, 2014:202).

Content analysis digunakan untuk menganalisis data interview transcription yang ditranscribe dari hasil wawancara. Langkah selanjutnya aktivitas analisis data Miles and Huberman dalam Satori dan Komariah (2014:218) terdiri atas: data reduction, data display dan conclusion drawing/verification yang dilakukan secara interaktif dan berlangsung secara terus menerus sampai tuntas, sehingga datanya mencapai jenuh. Analisis data yang dikembangkan pada penelitian ini adalah dengan editing, kategorisasi/coding dan meaning (Musfiqon, 2012).

\section{Analisis dan Pembahasan}

Penyaluran dana desa di Kecamatan Kotamobagu Selatan Kota Kotamobagu telah ditetapkan dengan Peraturan Walikota Kotamobagu Nomor 18a Tahun 2016 tentang Tata Cara Pembagian dan Penetapan Rincian Alokasi Dana Desa dan Dana Desa Setiap Desa di Kota Kotamobagu Tahun 2016. Kecamatan Kotamobagu Selatan memperoleh anggaran dana desa sebesar Rp. 5.298.986.000 yang dibagi kepada 6 (enam) desa yaitu desa poyowa besar satu, desa poyowa besar dua, desa tabang, desa bungko, desa kopandakan I dan desa poyowa kecil. Perhitungan dana desa di Kecamatan Kotamobagu Selatan dilakukan berdasarkan formula perhitungan dari alokasi dasar dan alokasi formula.

Alokasi formula yaitu alokasi yang dihitung dengan mempertimbangkan jumlah penduduk desa, angka kemiskinan desa, luas wilayah desa dan tingkat kesulitan geografis desa. Sedangkan alokasi dasar adalah alokasi minimal dana desa yang dibagi kepada seluruh desa di Indonesia secara merata.

Hasil penelitian dan pembahasan melalui wawancara langsung dengan informan terpilih yaitu pengelola dana desa di 6 (enam) desa dalam wilayah Kecamatan Kotamobagu Selatan dan Tim Fasilitasi Dana Desa Kota Kotamobagu. Sebagai perwakilan dari masyarakat peneliti melakukan wawancara langsung dengan Ketua BPD Desa Poyowa Besar Dua. Selain itu Observasi dilakukan dengan pengamatan langsung dilapangan dan mengamati kegiatan atau aktivitas dari informan. Selanjutnya melakukan studi dokumentasi dan membandingkan data wawancara, data observasi, dan data dokumentasi yang diperoleh selama penelitian yaitu kurang lebih 2 (dua) bulan.

Data wawancara, data observasi dan data dokumentasi kemudian dihimpun untuk dilakukan organisasi data. Untuk menjawab permasalahan "Akuntabilitas Pengelolaan Dana Desa Dalam Pelaporan dan Pertanggungjawaban di Kecamatan Kotamobagu Selatan Kota Kotamobagu," peneliti menemukan 8 (delapan) kategorisasi/coding atau tema.

\section{Manfaat Dana Desa}


Program pemerintah melalui pengalokasian dana desa yang bertujuan untuk memperbaiki kondisi dan taraf hidup masyarakat dalam rangka pembangunan nasional demi tercapainya kesejahteraan adil dan merata merupakan wujud nyata dari perhatian pemerintah pusat kepada pemerintah yang ada ditingkat bawah yaitu pemerintah desa dan manfaatnya sangat besar bagi masyarakat.

Dari pernyataan informan menunjukkan adanya tanggung jawab pemerintah pusat kepada masyarakat dalam pembangunan dengan mengalokasikan dana desa. Dimana sudah menjadi kewajiban pemerintah untuk meningkatkan taraf hidup masyarakat menuju masyarakat yang adil dan merata. Seperti yang dijelaskan oleh John Stuart Mill (1806-1873) bahwa semua tanggung jawab terhadap kewajiban sempurna yang memunculkan hak-hak memperoleh keadilan itu sendiri. Mill (1806-1873) menyimpulkan bahwa tidak ada teori keadilan yang bisa dipisahkan dari tuntutan kemanfaatan. Keadilan bagi Mill mensyaratkan aturan-aturan yang ditetapkan menjadi kebaikan masyarakat demi menjamin pemenuhan kewajiban-kewajiban tertentu yang keras demi melindungi hak-hak individu.

\section{Partisipatif}

Dalam pengelolaan dana desa pemerintah harus memberikan ruang lebih banyak kepada masyarakat untuk berpartisipasi aktif baik dalam perencanaan, pelaksanaan sampai pada pertanggungjawaban. Hal itu dilaksanakan dalam rangka melaksankan konsep dasar tingkat partisipasi masyarakat desa. Seluruh kegiatan yang didanai dana desa direncanakan secara terbuka melalui Musrenbangdes yang hasilnya dituangkan dalam peraturan desa tentang APBDes serta dilaksanakan dan diawasi secara terbuka dengan melibatkan seluruh unsur masyarakat desa.

Partisipatif (Sujarweni, 2015) adalah prinsip dimana setiap warga desa mempunyai hak untuk terlibat dalam setiap pengambilan keputusan pada setiap kegiatan yang diselenggarakan oleh pemerintah desa dimana mereka tinggal. Keterlibatan masyarakat desa dalam rangka pengambilan keputusan tersebut dapat secara langsung dan tidak langsung. Dengan demikian akuntabilitas pengelolaan dana desa telah membuka ruang politis bagi masyarakat untuk menjadi aktif terlibat dalam penyelenggaraan pengawasan pembangunan, sehingga berpotensi menciptakan proses pembangunan yang transparan, akuntabel dan partisipatif.

\section{Transparansi}

Untuk mendukung keterbukaan dan penyampaian informasi secara jelas kepada masyarakat, maka setiap pelaksanaan kegiatn fisik yang didanai oleh dana desa wajib dilengkapi dengan papan informasi kegiatan yang dipasang dilokasi kegiatan. Sebagaimana dalam ketentuan Peraturan Menteri Dalam Negeri Nomor 113 Tahun 2014 tentang Pengelolaan keuangan Desa menyebutkan bahwa pelaporan dan pertanggungjawaban pelaksanaan APBDes diinformasikan kepada masyarakat secara tertulis dan dengan media informasi yang mudah diakses masyarakat. Media informasi tersebut antara lain papan pengumuman. Jadi setiap kegiatan yang didanai oleh dana desa harus dilengkapi papan informasi/papan pengumuman.

Badan PMD, PP dan KB sebagai Tim Fasilitasi Dana Desa Kota Kotamobagu juga menyampaikan kepada setiap desa untuk penyediaan papan informasi. Papan informasi tersebut sekurang-kurangnya memuat nama kegiatan, volume kegiatan, besaran anggaran, sumber dana dari dana desa dan waktu pelaksanaan kegiatan. Namun pemerintah desa belum sepenuhnya melaksanakan atau belum menyediakan papan informasi tersebut.

Transparansi adalah memberikan informasi keuangan yang terbuka dan jujur kepada masyarakat berdasarkan pertimbangan bahwa masyarakat memiliki hak untuk mengetahui 
secara terbuka dan menyeluruh atas pertanggungjawaban pemerintah dalam pengelolaan sumber daya yang dipercayakan kepadanya dan ketaatannya pada peraturan perundangundangan (SAP, 2010). Guna mewujudkan pelaksanaan prinsip-prinsip transparansi dan akuntabilitas maka diperlukan adanya kepatuhan pemerintah desa khususnya pengelola dana desa untuk melaksanakannya sesuai dengan ketentuan yang berlaku.

Adanya komitmen bersama antara pemerintah desa dan masyarakat, dimana pemerintah desa (agent) bertanggungjawab kepada masyarakat sebagai pemberi amanah (principal) untuk melaksanakan pengelolaan dana desa dengan menerapkan prinsip transparansi dan akuntabel. Penggunaan dana yang telah direncanakan secara bersamasama yang merupakan usulan-usulan masyarakat, pemanfaatannya mencapai tujuan dan sasaran yang di inginkan. Seperti yang dijelaskan oleh DeGeorge (1992) dalam Smith \& bertozzi (1998) bahwa agent (pemerintah) terikat kontrak dengan principal (masyarakat) untuk bertindak atau melakukan pekerjaan seperti yang diinginkan oleh principal.

\section{Mekanisme pelaporan dan pertanggung-jawaban dana desa dilaksanakan sesuai ketentuan}

Untuk melaksanakan tata kelola yang baik maka pemerintah telah menetapkan kebijakan untuk penerapan sistem pertanggungjawaban yang jelas, teratur dan efektif yang disebut sistem akuntabilitas kinerja instansi pemerintah (SAKIP). Sistem akuntabilitas kinerja instansi pemerintah tertuang pada pasal 1 Peraturan Presiden Nomor 29 Tahun 2014 tentang Sistem Akuntabilitas Kinerja Instansi Pemerintah yang menyebutkan bahwa sistem akuntabilitas kinerja instansi pemerintah merupakan rangkaian sistematik dari berbagai aktivitas, alat dan prosedur yang dirancang untuk tujuan penetapan dan pengukuran, pengumpulan data, pengklarifikasian, pengikhtisaran dan pelaporan kinerja pada instansi pemerintah dalam rangka pertanggungjawaban dan peningkatan kinerja instansi pemerintah.

Dari sisi penerapan prinsip akuntabilitas sebagaimana dalam ketentuan Peraturan Menteri Dalam Negeri Nomor 113 Tahun 2014 tentang Pengelolaan Keuangan Desa dilaksanakan melalui sitem pelaporan realisasi dan pertanggungjawaban pelaksanaan APBDes.

Hasil penelitian menunjukkan bahwa laporan realisasi penggunaan dana desa sudah melalui mekanisme sesuai ketentuan. Hal ini merupakan salah satu tuntutan masyarakat yang harus dipenuhi oleh pemerintah desa dan merupakan bentuk pertanggungjawaban kepada pemerintah diatasnya sebagai institusi pemberi kewenangan.

Sabeni dan Gozali dalam Sujarweni (2015) menyatakan bahwa akuntabilitas merupakan suatu bentuk keharusan seseorang (pimpinan/pejabat/pelaksana) untuk meyakinkan bahwa tugas dan kewajibannya yang diembannya sudah dilaksanakan sesuai ketentuan yang berlaku. Mulgan (2003:3) menyatakan bahwa akuntabilitas menunjuk kepada mekanisme yang diberikan kepada pejabat publik untuk dapat menjelaskan dan memastikan bahwa mereka telah bertindak dengan benar, berperilaku etis serta bertanggungjawab atas kinerjanya.

\section{Sikap Pelaksana}

Penyusunan laporan realisasi APBDes dimana pengelolaan keuangan dana desa merupakan bagian yang tak terpisahkan dari pengelolaan keuangan desa dalam APBDes, yang pengelolaannya dilaksanakan oleh bendahara desa dan tim pengelola kegiatan (TPK). Dalam proses penyusunan laporan, bendahara desa menghadapi kendala. Seperti kelalaian dari pihak yang juga bertanggungjawab atas pengelolaan dana desa yaitu tim pengelola kegiatan (TPK) yang terlambat memasukkan bukti-bukti atau dokumen yang dibutuhkan oleh 
bendahara untuk melakukan pencatatan setiap penerimaan dan pengeluaran yang hasilnya menjadi satu dokumen pelaporan dan pertanggungjawaban. Kelalaian tim pengelola kegiatan (TPK) juga adalah tidak patuhnya terhadap mekanisme dimana setiap penerimaan dan pengeluaran dalam pelaksanaan kegiatan harus melalui verifikasi sekretaris desa, yang tugasnya adalah melakukan verifikasi terhadap bukti-bukti penerimaan dan pengeluaran APBDes.

Kelalaian ini mengakibatkan proses penyusunan laporan menjadi lambat yang pada akhirnya mempengaruhi pelaporan realisasi penggunaan dana desa semester pertama yang seharusnya disampaikan akhir bulan juli mengalami keterlambatan. Basri dan Nabiha (2014) menjelaskan bahwa akuntabilitas dalam sektor publik bukanlah hal yang mudah. Dibutuhkan moral, nilai, sikap dari pejabat pemerintah yang bertanggungjawab untuk pengelolaan dana masyarakat.

Edward III (1980) menjelaskan bahwa salah satu faktor penting dalam studi implementasi kebijakan adalah faktor sikap pelaksana. Jika implementasi kebijakan diharapkan dapat efektif, maka para pelaksana kebijakan tidak hanya sebatas mengetahui apa yang harus dilakukan, tetapi mereka juga harus memiliki dorongan, keinginan untuk melakukan tugas tersebut. Perilaku pelaksana yang kurang berpartisipasi aktif dapat menghambat efektivitas implementasi kebijakan.

\section{Struktur Birokrasi}

Untuk penyaluran dana desa di Kota Kotamobagu telah diatur dalam Peraturan Walikota Kota Kotamobagu Nomor 18a tentang Tata Cara Pembagian dan Penetapan Rincian Alokasi Dana Desa dan Dana Desa disetiap Desa di Kota Kotamobagu Tahun Anggaran 2016. Penyaluran dana desa dilakukan melalui pemindahbukuan dari Rekening Kas Umum Daerah ke Rekening Umum Kas Desa. Untuk penyaluran dana desa tahap I dilakukan setelah kepala desa menyampaikan peraturan desa mengenai RPJMDes, RKPDes, APBDes dan laporan realisasi penggunaan dana desa tahun anggaran sebelumnya. Dalam penyampaiannya kepala desa harus menyampaikan paling lambat minggu kedua bulan maret. Namun pada pelaksanaannya pemerintah desa terlambat menyampaikan dokumen-dokumen tersebut sebagai persyaratan untuk penyaluran dana desa tahap I yaitu pada bulan maret berdasarkan Peraturan Walikota Kota Kotamobagu Nomor 18a Tahun 2016. Keterlambatan tersebut disebabkan adanya pergantian kepala desa yang baru dimana kewajiban dari pemerintah desa untuk membuat RPJMDes, RKPDes dan APBDes tahun 2016 yang membutuhkan waktu yang lama yaitu kurang lebih 3 (tiga) bulan tentunya juga akan memperlambat penyampaian dokumen-dokumen untuk persyaratan pencairan dana desa. Adapun kendala lain sehingga terjadi keterlambatan penyaluran dana desa tahap I adalah regulasi yang turun dari pemerintah pusat ke pemerintah daerah terlambat dan berubahrubah.

Hal ini mencerminkan bahwa struktur birokrasi bisa menghambat implementasi kebijakan. Meskipun sumber daya untuk mengimplementasikan kebijakan mencukupi dan para pelaksana mengetahui apa yang harus dilakukan serta bersedia melaksanakannya, namun Implementasinya masih terhambat oleh permasalahan struktur birokrasi.

Wahab (2008:185) menjelaskan fungsi kebijakan implementasi kebijakan itu adalah membuat suatu hubungan yang memungkinkan tujuan-tujuan ataupun sasaran-sasaran kebijakan negara dilaksankan dan diwujudkan sebagai outcome (hasil akhir) kegiatankegiatan akhir yang diinginkan pemerintah, mampu untuk melaksanakan apa yang sudah menjadi ketentuan dan menginginkan apa yang ada di ketentuan dapat tercapai guna mendukung keberhasilan implementasi sebuah kebijakan negara namun masih terhambat struktur birokrasi yang ada. 
Keterlambatan penyaluran dana desa tahap I tentunya juga menyebabkan keterlambatan dalam penyerapan atau realisasi penggunaan dana desa yang mengakibatkan pada keterlambatan penyampaian laporan realisasi pelaksanaan APBDes semester pertama. Dalam Peraturan Menteri Dalam Negeri Nomor 113 Tahun 2014 tentang Pengelolaan Keuangan Desa yang menyebutkan bahwa penyampaian laporan realisasi pelaksanaan APBDes semester pertama disampaikan paling lambat pada akhir bulan juli tahun berjalan dengan realisasi penggunaan atau penyerapan anggaran paling kurang sebesar $50 \%$ (lima puluh persen). Namun hal itu tidak dapat dilaksankan oleh pengelola dana desa karena waktu yang sangat terbatas tidak memungkinkan bagi pengelola dana desa untuk secepatnya merealisasikan penggunaan anggaran.

Peran aparat desa sebagai pengelola dana desa sangat diperlukan dalam menentukan tindakan untuk penentuan arah penggunaan dana desa agar dapat mencapai tujuan atau target yang telah diatur dalam ketentuan, meskipun dalam implementasinya masih mengalami keterlambatan dan diberhadapkan pada kondisi situasional yang dapat membatasi tindakan untuk mencapai tujuan tersebut.

Parson (Ritzer, 1992:47) menjelaskan teori aksi ditempatkan pada paradigma difinisi sosial oleh konsep voluntarisme parsons. Konsep Voluntarisme ini adalah pelaku aktif dan kreatif serta mempunyai kemampuan menilai dan memilih dari altrenatif tindakan. Walaupun aktor tidak memiliki kebebasan total namun ia memiliki kemampuan bebas dalam memilih berbagai alternatif tindakan, berbagai tujuan yang hendak dicapai, kondisi dan norma serta situasi penting yang mempengaruhinya dalam memilih dan menentukan tujuan serta tindakan untuk mecapai tujuan.

\section{Faktor Komunikasi}

Akuntabilitas pengelolaan dana desa tidak hanya terwujudnya pelaporan dan pertanggungjawaban yang benar, tetapi diwujudkan dengan pengelolanya yang memahami atau mengetahui apa yang harus dilakukan. Perintah untuk mengimplemen-tasikan kebijakan harus disampaikan secara jelas, akurat dan konsisten kepada orang-orang yang mampu.

Dari pengamatan dilapangan, pengelola dana desa yang kurang paham dalam sistem penyetoran pajak dengan aplikasi e-billing menyebabkan keterlambatan dalam penyetoran pajak. Sebelumnya juga tidak ada informasi melalui surat pemberitahuan ataupun sosialisasi dari instansi terkait yaitu KPP Pratama.

Tidak adanya informasi maupun sosialisasi dari instansi terkait yaitu KPP Pratama sehingga penyetoran pajak yang dilakukan oleh bendahara desa mengalami keterlambatan dan akhirnya menjadi temuan Inspektorat. Faktor komunikasi merupakan hal yang sangat penting guna mendukung keberhasilan implementasi kebijakan. Robin (2006) menyatakan bahwa komunikasi menjalankan empat fungsi utama di dalam kelompok atau organisasi yaitu pengendalian, motivasi, pengungkapan emosi dan informasi.

Tidak adanya sosialisasi maupun informasi dari instansi terkait sehingga menghambat kesuksesan implementasi kebijakan publik yaitu keterlambatan dalam penyetoran pajak ke kas negara.

\section{Kompetensi}

Dalam pengelolaan dana desa dibutuhkan kecakapan atau ketrampilan dari pengelolanya. Kepala desa dalam melaksanakan pengelolaan dana desa dibantu oleh PTPKD yang berasal dari unsur perangkat desa salah satunya adalah bendahara desa yang mempunyai tugas melaksanakan pengadminitrasian laporan pertanggungjawaban. Namun dalam menyusun laporan pertanggungjawaban masih ada yang belum dipahami oleh 
bendahara desa. Hal tersebut karena kurangnya pemahaman bendahara desa mengenai peraturan dan kurangnya pengetahuan maupun informasi untuk mendukung tugastugasnya.

Tingkat kemampuan bendahara desa masih perlu diupayakan guna peningkatan kompetensi. Kompetensi tersebut merupakan perpaduan antara motivasi, sikap, watak, pengetahuan dan kemampuan yang harus selalu diupayakan peningkatan secara berkelanjutan. Bendahara desa harus memiliki keinginan untuk mempelajari hal-hal baru khususnya dalam pengelolaan keuangan desa untuk mendukung tugas-tugasnya.

Spencer (1939:9) dalam Sedarmayanti (2015) menjelaskan bahwa kompetensi adalah bagian dari kepribadian yang mendalam dan melekat pada seseorang, serta perilaku yang dapat diprediksi pada berbagai keadaan dan tugas pekerjaan.

Guna mendukung kemampuan pengelola dana desa dalam peningkatan kompetensi, tim fasilitasi dana desa Kota Kotamobagu yaitu Badan PMD, PP dan KB Kota Kotamobagu, dan Dinas BPKD Kota Kotamobagu telah beberapa kali memberikan pelatihan, sosialisasi dan pendampingan kepada pengelola dana desa yaitu Kepala Desa, Sekretaris Desa, Bendahara Desa dan PTPKD. Disamping itu tim fasilitasi memberikan konseling langsung turun di lapangan dan memberikan ruang kepada pengelola dana desa untuk konsultasi. Pelatihan ini dilaksanakan bekerjasama dengan BPKP yaitu pelatihan pengelolaan keuangan desa berbasis

$\mathrm{IT}$, tentang tata cara penginputan dengan menggunakan aplikasi siskeudes.

Dalam mewujudkan akuntabilitas pengelolaan dana desa harus didukung dengan sumber daya yang memadai agar tujuan-tujuan yang ingin dicapai dapat terwujud. Tanpa individu yang memiliki keahlian atau kompetensi maka mustahil bagi organisasi dapat mencapai tujuan. Yusuf (2015) mendefinisikan sumber daya sebagai alat untuk mencapai tujuan atau kemampuan memperoleh keuntungan dari kesempatan-kesempatan yang ada. Werther dan Davis (1996) menyatakan bahwa sumber daya manusia adalah pegawai yang siap, mampu dan siaga dalam mencapai tujuan organisasi.

\section{Penutup}

Akuntabilitas Pengelolaan Dana Desa Dalam Pelaporan dan Pertanggungjawaban di Kecamatan Kotamobagu Selatan Kota Kotamobagu dapat diambil kesimpulan sebagai berikut.

1. Manfaat dana desa di Kecamatan Kotamobagu Selatan Kota Kotamobagu telah nampak dan dirasakan oleh masyarakat terutama pada pembangunan infrastruktur dan pemberdayaan yang menjadi prioritas penggunaan dana desa berdasarkan ketentuan perundang-undangan.

2. Perencanaan program dana desa telah menerapkan prinsip akuntabel, transparan dan partisipatif dimana perencanaannya dilaksanakan melalui forum musrenbangdes (Musyawarah Rencana Pembangunan Desa). Masyarakat secara terbuka memberikan usulan-usulan dalam perencanaan pembangunan desa yang dituangkan dalam RPJMDes, RKPDes, APBDes, dan pemerintah desa pun secara terbuka menerima usulanusulan dan ditetapkan bersama dengan BPD.

3. Pelaksanaannya telah menerapkan prinsip transparan, akuntabel dan partisipatif dengan melibatkan masyarakat dalam kegiatan terutama pembangunan fisik dan masyarakat juga langsung mengawasi dalam kegiatan pembangunan. Selain itu masyarakat dengan mudah mengakses informasi melalui papan pengumuman/papan informasi meskipun penggunaan papan informasi ini belum maksimal karena tidak semua kegiatan dibuatkan papan informasi. Penyampian informasi juga dilakukan secara langsung oleh 
kepala desa kepada masyarakat melalui rapat, kegiatan keagamaan dan ditempat dimana biasanya masyarakat berkumpul.

4. Akuntabilitas dalam pelaporan dan pertanggungjawaban dana desa dilaksanakan sesuai dengan mekanisme berdasarkan ketentuan walaupun masih terdapat kelalaian aparat desa dan tim pengelola kegiatan. Sistem pelaporan dan pertanggungjawaban sudah dipermudah dengan aplikasi siskeudes (sistem keuangan desa). Penetapan laporan pertanggungjawaban pelaksana-an APBDes tidak hanya melibatkan pengelola keuangan desa tetapi melibatkan juga unsur masyarakat dimana BPD sebagai pengawas pengelolaan dana desa berhak untuk memberikan penilaian atas kinerja pemerintah desa dan hasil-hasil pembangunan melalui musyawarah yang dilaksankan setiap akhir tahun.

RPJMDes, RKPDes, APBDes dan laporan realisasi penggunaan dana desa tahun sebelumnya sebagai persyaratan untuk pencairan dana desa tahap I tidak tepat waktu sebagaimana dalam ketentuan. Pemerintah desa terlambat menyampaikan kepada pemerintah Kota Kotamobagu, sehingga pencairan dana desa tahap I mengalami keterlambatan. Selain itu regulasi yang berubah-ubah dari pemerintah pusat berdampak pada proses penyaluran dana desa tahap I mengalami keterlambatan yang mempengaruhi penyerapan atau realisasi penggunaan dana desa yang tidak memenuhi target sesuai dengan ketentuan. Hal ini menjadi kendala pemerintah desa sehingga laporan realisasi APBDes semester pertama mengalami keterlambatan dalam penyampaian kepada Walikota Kotamobagu. Dalam pelaporan dan pertanggungjawaban kompetensi sumber daya manusia masih merupakan kendala utama, sehingga masih perlu pendampingan dari aparat pemerintah daerah yaitu tim fasilitasi dana desa Kota Kotamobagu.

\section{Saran}

Ada beberapa hal yang dapat disarankan dan menjadi perhatian dalam bagi pengelolaan dana desa :

1. Untuk meningkatkan akuntabilitas pengelolaan dana desa di Kecamatan Kotamobagu Selatan Kota Kotamobagu maka disarankan agar pembinaan dan pelatihan pengelolaan keuangan desa terus dilakukan oleh pemerintah daerah kepada pengelola dana desa untuk mengatasi kurangnya pemahaman, kemampuan dan keahlian aparat desa sehingga dalam mengimple-mentasikan program dana desa dapat berjalan lancar dan tidak mengalami kendala khususnya dalam pelaporan dan pertanggung-jawaban.

2. Perlunya melakukan pengawasan terhadap pengelolaan keuangan desa, karena masih lemahnya aspek sumber daya manusia.

3. Melakukan monitoring dan evaluasi secara berkelanjutan untuk memperbaiki pengelolaan baik fisik, teknis, maupun administrasi pelaporan dan pertanggungjawaban.

4. Perlunya dibuatkan Peraturan Walikota tentang sistem akuntabilitas pengelolaan dana desa ditingkat desa dan kecamatan untuk meminimalisir kesalahan dalam pengelolaan dana desa. Hal ini juga sebagai upaya untuk meningkatkan akuntabilitas baik dalam pelaporan dan pertanggungjawaban maupun dalam akuntabilitas kinerja pemerintah desa.

\section{Keterbatasan Penelitian}

Keterbatasan dalam penelitian ini adalah:

1. Waktu yang singkat untuk melakukan penelitian yaitu kurang lebih 2 (dua) bulan. 
2. Penelitian ini difokuskan pada pelaporan dan pertanggungjawaban berdasarkan latar belakang masalah.

\section{Daftar Pustaka}

Basri, H dan Siti Nabiha. 2014. Accountability of Local Government: The Case of Aceh Province Indonesia. Graduate School of Business University Sains Malaysia.

Kota Kotamobagu, 2016. Perubahan atas Peraturan Walikota Kotamobagu Nomor 4 tahun 2016 tentang Tata Cara Pembagian dan Penetapan Rincian Dana Desa di setiap Desa di Kota Kotamobagu Tahun Anggaran 2016. Peraturan Walikota Nomor 18a

Lebacqz, Karen. 1986. Teori-teori Keadilan. Terjemahan Yudi Santoso. Bandung : Nusa Media Mardiasmo, 2002. Akuntansi Sektor Publik. Yogyakarta : Andi

Mulgan, R. 2000. Accountability : An Ever - Expanding Concept. Journal Public Administration, Vol.78, No. 3: 555-576

Musfiqon, 2012. Panduan Lengkap Metodologi Penelitian Pendidikan. PT. Prestasi Pustakaraya. Jakarta

Republik Indonesia. 2014. Pengeloaan Keuangan Desa. Peraturan Menteri Dalam Negeri No. 113

Presiden No. 29 . 2014. Sistem Akuntabilitas Kinerja Instansi Pemerintah. Peraturan

.2014. Dana Desa Yang Bersumber Dari Anggaran Pendapatan Dan Belanja Negara. Peraturan Pemerintah No. 60 . 2014. Desa.Undang-Undang No.6

2010. Standar Akuntansi Pemerintahan. Peraturan Pemerintah Nomor 71

Satori, Djam'an dan Aan Komariah. 2014. Metodologi Penelitian Kualitatif. Bandung: Cv. Alfabeta

Sedarmayanti, 2016. Sumber Daya Manusia. Refika Aditama Bandung

Smith, W. Robert and Mark Bertozzi. 1998. Principals and Agents : An explanatory model of public budgeting. Journal of Public Budgeting and Financial Management (Fall): 325-353

Subroto, 2008. Akuntabilitas Pengelolaan Dana Desa (Studi Kasus Pengelolaan Alokasi Dana Desa di Desa-Desa Dalam Wilayah Kecamatan Tlogomulyo Kabupaten Temanggung. Tesis : Program Studi Magister Sains Akuntansi Program Pasca Sarjana Universitas Diponegoro

Sugiyono, 2015. Metode Penelitian Manajemen.Alfabeta Bandung

Sujarweni, Wiratna. 2015. Akuntansi Desa. Yogyakarta : Pustaka Baru Press

Yusuf, Burhanudin. 2015. Manajemen Sumber Daya Manusia di Lembaga Keuangan Syariah. Jakarta : PT. Raja Grafindo Persada. 